\title{
Hepatic portal venous gas after radical cholangiocarcinectomy
}

\author{
Le-Xin Bao, Xiao Hu, Wei-Dong Guo \\ Department of Hepatobiliary and Pancreatic Surgery, the Affiliated Hospital of Qingdao University, Qingdao, China
}

Correspondence to: Dr. Wei-Dong Guo. Department of Hepatobiliary and Pancreatic Surgery, the Affiliated Hospital of Qingdao University, No. 16, Jiangsu Road, Qingdao, China. Email: 1848348427@qq.com.

Submitted Apr 13, 2020. Accepted for publication Jul 03, 2020.

doi: 10.21037/qims-20-565

View this article at: http://dx.doi.org/10.21037/qims-20-565

A 63-year-old female patient was hospitalized for cholangiocarcinoma and underwent radical cholangiocarcinectomy and Roux-en-Y choledochojejunostomy. The postoperative exsuffation time was the third day after operation, and then the patient began to take a small amount of liquid meal. The patient complained about occasional nausea and vomiting after the meal. Radiography of upper gastrointestinal with meglumine diatrizoate showed a slight reduction in gastrointestinal motility. The patient was advised to limit food intake and continue intravenous nutrition therapy. On the 17 th day after the operation, the patient had a fever with the body temperature ranging from 38.5 to $39^{\circ} \mathrm{C}$. Computed tomography (CT) scan showed biliary pneumatosis. Hepatic portal venous gas (HPVG) was not noted at this stage. Laboratory tests revealed high white blood cell count $\left(11.6 \times 10^{9} / \mathrm{L}\right.$, normal value $\left.3.5-9.5 \times 10^{9} / \mathrm{L}\right)$, elevated percent of neutrophils $(83.6 \%$, normal value $40-75 \%)$, elevated C-reactive protein (112 mg/L, normal value $0-5 \mathrm{mg} / \mathrm{L}$ ), abnormal liver function tests with increased Direct Bilirubin $(10.2 \mu \mathrm{mol} / \mathrm{L}$, normal value 0-8 $\mathrm{mol} / \mathrm{L}$ ), alanine aminotransferase (247 U/L, normal value 7-40 U/L), aspartate aminotransferase (149 U/L, normal value $13-35 \mathrm{U} / \mathrm{L})$, alkaline phosphatase (247 U/L, normal value 50-135 U/L) and gammaglutamyl transpeptidase ( $345 \mathrm{U} / \mathrm{L}$, normal value 7-45 U/L). In consideration of the recurrent fever after choledochojejunostomy, the patient was given physical defervescence and took antipyretic drug and lactulose by oral administration. After conservative treatment, the patient still had recurrent fever and felt epigastric distention. On the 20th day after the operation, the patient had fever with the body temperature of $39.5^{\circ} \mathrm{C}$ and complained of severe epigastric pain. Emergent CT showed extensive branching and tubular gas density shadows in the liver, and large low-density shadow in right lobe of liver (Figure 1A). Laboratory tests revealed high white blood cell count $\left(15.1 \times 10^{9} / \mathrm{L}\right.$, normal value $\left.3.5-9.5 \times 10^{9} / \mathrm{L}\right)$, elevated percent of neutrophils ( $91.1 \%$, normal value $40-75 \%)$, reduced platelet $\left(15 \times 10^{9} / \mathrm{L}\right.$, normal value $\left.128 \times 10^{9}-350 \times 10^{9} / \mathrm{L}\right)$, elevated C-reactive protein $(239 \mathrm{mg} / \mathrm{L}$, normal value $0-5 \mathrm{mg} / \mathrm{L})$, elevated procalcitonin $(3.2 \mathrm{ng} / \mathrm{mL}$, normal value $<0.05 \mathrm{ng} / \mathrm{L}$ ), abnormal liver function tests with increased total bilirubin $(67 \mu \mathrm{mol} / \mathrm{L}$, normal value $3-22 \mu \mathrm{mol} / \mathrm{L})$, alanine aminotransferase (4,502 U/L, normal value 7-40 U/L), and aspartate aminotransferase (2,696 U/L, normal value 13-35 U/L). Severe biliary tract infection, hepatic abscess, and HPVG were suspected. Dark brown pus was drained by percutaneous transhepatic drainage, and the bacterial culture indicated infection of enterobacter aerogenes. After drainage and conservative treatment, the patient's clinical symptoms improved significantly, and the abnormal liver function index decreased rapidly. One week later, CT scan revealed that the symptoms of HPVG disappeared (Figure 1B). In addition, CT scan also revealed multiple focal low densities in the liver. Considering that the patient had experienced severe infection, we considered that these were ischemic semi-necrotic foci. As the symptoms improved, the patient was discharged. The patient was advised to have CT follow-up. The most recent CT scan was 2 months after percutaneous transhepatic drainage (Figure 1C). The patient recovered well, and the drainage tube was removed.

HPVG is a severe radiological symptom in which gas accumulates in the portal venous system $(1,2)$. Bowel ischemia is the most common etiologic cause for HPVG (3). Other causes include inflammatory bowel disease, sepsis, abdominal trauma and iatrogenic injuries (1). For this case, 

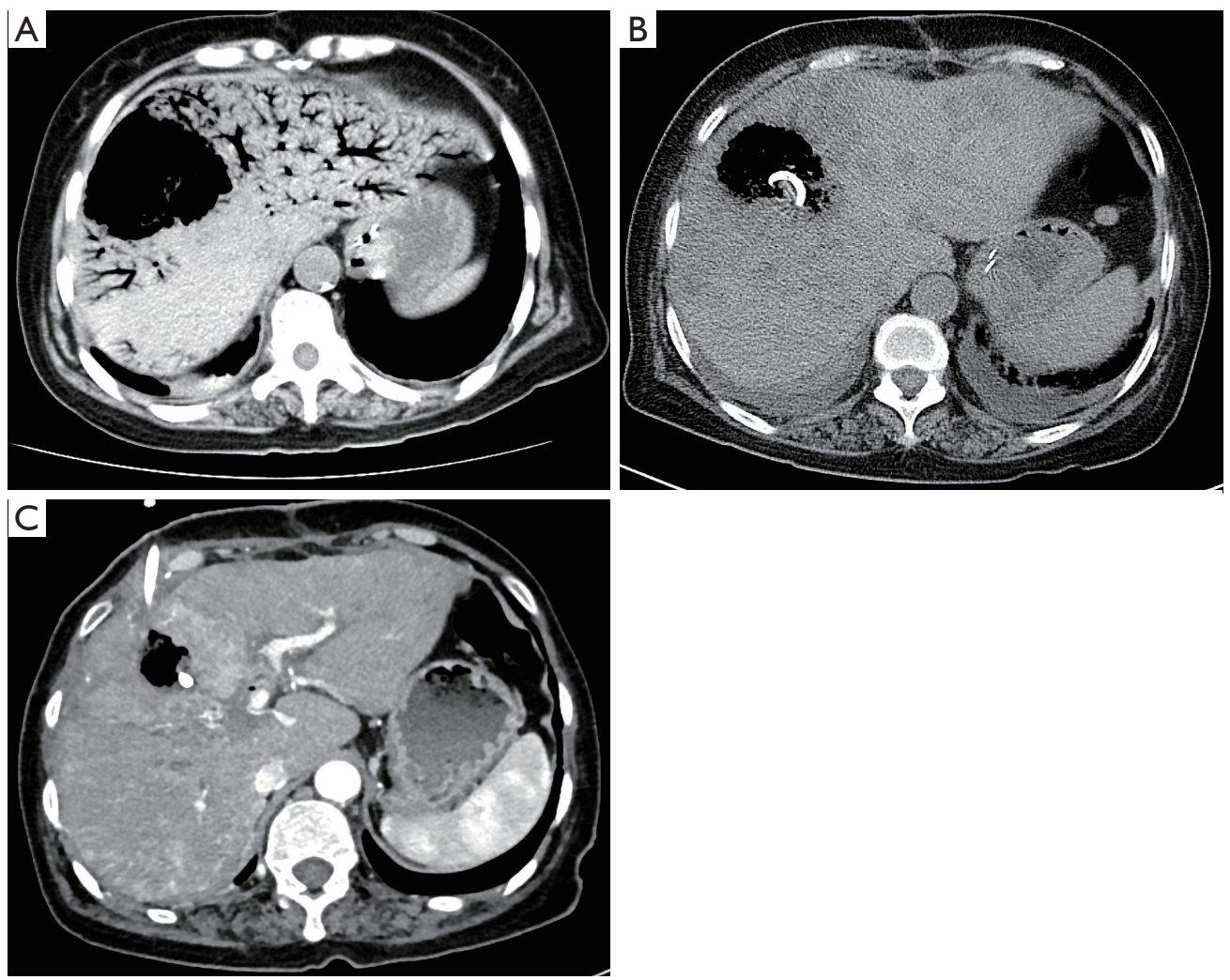

Figure 1 CT shows extensive gas within the intrahepatic portal venous system on the 20th day after the surgical operation (A); (B,C) show CT 1 week and 2 months after percutaneous transhepatic drainage respectively. CT, computed tomography.

CT scan revealed no obvious intestinal lesions. Bacterial culture of blood and drainage fluid indicated infection of enterobacter aerogenes. This result suggested that the HPVG in this patient was caused by enterobacter aerogenes infection. The bacterial translocation may be related to the patient's age, poor physical condition and long-term intravenous nutrition. Clinically, it is often necessary to differentiate HPVG from biliary pneumatosis. However, in this case, both occurred. Supportive conservative treatment and timely percutaneous drainage are the key to achieve good prognosis in this case. At present, although there is no evidence that biliary pneumatosis can cause HPVG, patients with biliary pneumatosis still need to be carefully observed for changes in symptoms.

\section{Acknowledgments}

Funding: None.

\section{Footnote}

Conflicts of Interest: All authors have completed the
ICMJE uniform disclosure form (available at http://dx.doi. org/10.21037/qims-20-565). The authors have no conflicts of interest to declare.

Ethical Statement: Written informed consent was obtained from the patient for publication of this study and any accompanying images.

Open Access Statement: This is an Open Access article distributed in accordance with the Creative Commons Attribution-NonCommercial-NoDerivs 4.0 International License (CC BY-NC-ND 4.0), which permits the noncommercial replication and distribution of the article with the strict proviso that no changes or edits are made and the original work is properly cited (including links to both the formal publication through the relevant DOI and the license). See: https://creativecommons.org/licenses/by-nc-nd/4.0/.

\section{References}

1. Abboud B, El Hachem J, Yazbeck T, Doumit C. Hepatic 
portal venous gas: physiopathology, etiology, prognosis and treatment. World J Gastroenterol 2009;15:3585-90.

2. Kinoshita H, Shinozaki M, Tanimura H, Umemoto Y, Sakaguchi S, Takifuji K, Kawasaki S, Hayashi H, Yamaue H. Clinical features and management of hepatic portal venous gas: four case reports and cumulative review of the literature. Arch Surg 2001;136:1410-14.

3. Liebman PR, Patten MT, Manny J, Benfield JR, Hechtman HB. Hepatic--portal venous gas in adults: etiology, pathophysiology and clinical significance. Ann Surg 1978;187:281-7.

Cite this article as: Bao LX, Hu X, Guo WD. Hepatic portal venous gas after radical cholangiocarcinectomy. Quant Imaging Med Surg 2020;10(12):2376-2378. doi: 10.21037/qims-20-565 